\title{
Conceptual Framework to Study Peasant Society and Economy*
}

\author{
Dr. Shanker Thapa**
}

\section{Introduction:}

Theoretical basis in the analysis of historical contexts of various aspects of peasant society has been an important tool for historians. The analysis of historical aspects or other context of peasant society aided by a conceptual framework is necessary. Historical contexts and events need analysis within the approved paradigm for better understanding and analysis of peasant behaviour. In fact, such analyses demand certain level of knowledge of theoretical approaches used as the tool previously to study peasant societies. Such kind of theoretical knowledge helps to evaluate the radical nature of peasantry among other features in all societies. The application of approved theoretical model in the analysis of peasant societies could help to derive two fundamental contradictions surrounding the peasantry. The first one is the contradiction between the dynamic growth of capitalism and persistence of landownership that is pre-capitalist in form. The other is the contradiction between agrarian bourgeoisie and a proletariat in agriculture.

The views of Marx, Lenin and Mao on peasantry, agrarian relations and capitalist agriculture, and the communist tenets have greater impact on radical orientation of peasant societies in Asia. Middle class intellectuals mostly led regional Communist parties in Asia. This context always had important role in the ideological growth within the peasant society. Therefore, an analysis of peasant activities within a conceptual frame is necessarily required to come across the strategy, organizational development and revolutionary potential of peasantry. First, historical approach leads to chronological description as a tool to interpret the political economy of radical peasant activities. In fact, development of communism and its penetration in Asia is the root to originate peasant

This article is a part of research pursued in Korea under the 'Korea Foundation Field Research Fellowship' from May to November 2005 under the theme Peasant Radicalism. The author extends thanks to Mr. Hwang, Director, Ms. Park Mi Sook, Deputy Director and Mr. Seung Heun Rhee, Programme Officer in the Fellowship Department of the Korea Foundation for their kind help during research.

** Dr. Shanker Thapa is an Associate Professor in the Central Department of History, Tribhuvan University, Kathmandu. 
radicalism in Asian societies, and in turn, peasantry served as the source of mobilization for the communists.

There are ample references that Asian peasantry showed militant revolutionary tendencies repeatedly since the early years of Asian revolutions. The ceaseless disturbances and class conflict in various Asian societies occurred only after the end of the Second World War. Without removing colonial and feudalistic remnants, modern history deteriorated into deep fetters. ${ }^{1}$ In colonies, there existed tendencies such as foreign bourgeoisie class, exploited and alienated proletariats, foreign oriented social ideologies and thoughts; and cultural and academic dependencies. Those situations were the major causes of chaotic situations. This kind of situation was mostly common in the past. Since the ancient times, China held supremacy over East Asia. However, in modern times, Japan became the leader in the East Asian region and the British had political control over South and South East Asia. This situation was far more responsible for penetration of revolutionary ideals among the political activists as well as the peasantry. It has disintegrated traditional social values and order. In fact, incompetent ruling classes or autocratic regimes were no longer to sustain national identity or sovereignty, while oppressed masses, poor peasantry and isolated intellectuals fought against the imperialists and the feudal states. In many cases, movements of oppressed and toiling Asian peasantry started with their economic grievances, but later on those movements developed into the struggle against the feudal state. More importantly, those movements developed into class struggles. The Taiping revolution of China (185164) ${ }^{2}$ and Gab-O revolution of Korea (1894) ${ }^{3}$ are such examples. There occurred many peasant movements in other South Asian countries as well which paralleled those revolutions in terms of the nature of class conflict. $^{4}$

1 Chung Tae Shin, 'A Socio-Economic Analysis of Gab-O Peasant Revolution in Korea’, (Unpublished Ph. D. Dissertation), Michigan State University, 1988, p. 1.

2 Yu Wen Jen, The Taiping Revolutionary Movement, Taipei: Rainbow Bridge Book Company, 1975, p. 120.

3 Kang Jae Eun, 'Gab-O Peasant War of the Breakage of Feudalism in Korea', in Ahn Byung Gik and Park Seong Soo (eds.), Hanguk Geundae Minkjok Undongsa, Seoul: Dolbaegae Publishing Co., 1980, pp. 7 -35.

4 Very few researches were done on the theme in South Asian countries other than India. Some of the important researches done so far on Indian and other South Asian peasantry are: Sirin Akhtar, The Zamindars of Bengal, Dhaka: The Asiatic Society of Bangladesh, 1982; Dietmar Rothermund, "Government, Landlords and Tenants in India' (Reprinted from-Indian Socio-Economic and Historical Review, Vol. VI, no. 4, Dec. 1968.); A.R. Desai, Peasant Struggle in India, Bombay: 
S. Thapa, Conceptual framework in the ...

Agrarian structure and peasant economies transformed through capitalist development under the impact of wider historical forces. History of Asian peasantry revives certain classical agrarian questions $-^{5}$

- Does the penetration of capitalist development go far enough to transform peasant economy?

- Is there any inevitable process, which converts peasantry into a rural proletariat?

- Are we witnessing the last remnants of a traditional social structure? and

- Do certain non-capitalist forms of production and organization persist within a predominantly capitalist model?

The two overreaching theories of peasant studies particularly the Marxist and Chayanovian perspectives took agrarian questions with concomitant understanding of agrarian transformation

Marxists believe that incorporation of a peasant economy into a capitalist system will lead to disintegration of the peasant household and proletariatization of peasant economy. On the other hand, the Chayanovians argue that peasant economy constitutes its own rules of production and consumption. Therefore, agrarian sector would not disappear, thus causing a separate economic type and a particular form of culture. The Marxist approach of peasantry is inclined to isolate historical structural factors generating the transformation of peasantry towards proletariatization rather than to specify the mechanism of transformation. The Chayanovian view delimits its focus to the internal dynamics of the peasant household. However, both perspectives failed to capture the real complexity of agrarian transformations and peasant economies. Both of the perspectives are one sided and face a fundamental problem as theories. In fact, theory has value so far as it explains reality and helps make sense events. ${ }^{6}$ All history is contemporary history. ${ }^{7}$ Therefore, historical events demand reinterpretation from the viewpoint of

Oxford University Press, 1979; D.N. Dhanagare, Peasant Movements in India 1920-1950, Oxford University Press, 1994; Atiur Rahaman, Peasant and Classes: A Study of Differentiation in Bangladesh, Delhi: Oxford University Press, 1986; Shanker Thapa, Agrarian Relations in Nepal, New Delhi: Adroit Publisher, 2000; Shanker Thapa, Peasant Insurgence in Nepal, Bhaktapur: Nirmala K.C., 2003.

5 Park Gil Sung, 'The Making of Peasant Household Economy and Demography to Capitalist Industrialization in Rural Korea' (Unpublished Ph.D. Dissertation), University of Wisconsin, 1988, pp. 1-2.

$6 \quad$ F. Mallon, Defense of Community in Peru's Highlands: Peasant Struggle and Capitalist Transition 1869-1940, Princeton: Princeton University Press, 1983, p. 7.

7 E.H. Carr, What is History?, New York: Random House, 1961, p. 5. 
contemporary history. It helps to evaluate properly the Asian peasant insurgencies that emerged as class struggle or its prototype in the Asian feudal set up. Peasant insurgencies in Asia incorporated radical features in general. Marx's theory of history insists that different socio-economic organizations of production characterize human history arise or fall. The growth of productive forces explains the course of human history. ${ }^{8}$ by The level of development of productive forces explained. ${ }^{9}$ Marx offers his theory of history not simply as a research The nature of production is a tool, which masses of people might take up to change the world through revolutions. Thus, his theory of history is described accordingly -

Feudalism

Bourgeoisie democratic revolution

Capitalism

Proletariat revolution

Worker's state (transition society)

Lower stage of communism (Socialism)

Full stage of communism

This is the diagrammatical presentation of Marx's theory of historical development.

\section{Modern Approaches to Analyze Peasantry}

Peasantry, on the basis being the force of population has different faces. The first types of Peasantry produce for consumption. The household needs primarily determine the productivity by. Beyond that price, supply and demand, cost and returns have major role in production related decisions of the peasantry. This section of peasants has similarities with a capitalist enterprise. In the next stage, peasantry acted as the member of the stratified society, whose surplus supported the consumption needs of the non-agricultural population. Modern economists have studied these characteristic features and roles of peasants. Theodore Schultz argues that peasantry was, in fact, an enterprising and optimizing user of resources within the traditional agricultural practices. His peasants are economic men no less than any other capitalist entrepreneurs are. ${ }^{10}$ Schultz has proposed that it is necessary to leave small family farm structure of productive organization

8 G. A. Cohen, Karl Marx's Theory of History, Princeton: Princeton University Press, 1978, pp. 28-62 and 134-173.

9 William H. Shaw, 'Historical Materialism and Development Thesis', Philosophy and Social Science, Vol. 16, 1986, pp. 197-210.

10 Theodore W. Schultz, Transforming Traditional Agriculture, New Heaven: Yale University Press, 1964, Chapters 2 and 3. 
in tact rather than tampering with it and to provide modern factors of production at prices within the economic reach of the small peasant to transform traditional agriculture. This was done in the Soviet Union. Once proper economic incentives for innovation are present, the entrepreneurial family farmer will innovate to modernize agriculture in much the same manner as had happened in American agriculture.

Prof. Samuel L. Popkin has explained in detail the peasants' political behaviour. For him, peasant farm is best described with the analogy of a capital firm and peasant as a political actor. ${ }^{11}$ He thought that peasants act to maximize production of grain by rationalizing production and balancing short and long-term interests similar in the way a capitalist firm or investor does. He tried to improve Schultz's perception of peasant behaviour taking into account of the element of risk in peasant agriculture. He borrowed ideas mostly from Milton Friedmann's 'class analysis of consumer choice' under conditions of risk. Michael Lipton's 'analysis of the nature of rational behaviour when survival not profit is the paramount consideration', ${ }^{12}$ and Marxist ideology criticize James Scott's substantivist analysis.

A. Chayanov argued in his classical theoretical analysis based on the studies of Russian peasants in 1920s that peasant economies is difficult to understood in conventional terms of the discipline which is developed for the study of capitalist economies. Capitalist profit accounting is not applied to a peasant family farm on which there is little or no wage labor. Most of all, peasant family farm produced for the satisfaction of the family's consumption needs, not for profit maximization. Karl Polanyi has contributed a lot against the use of conventional economics to study peasant economy. For him, analytical concepts and methods of conventional economics are predicated, above all, on the existence of price making markets. ${ }^{13}$ The application of such concepts to pre-market economies is actually nothing more than the universalizing of utilitarian rationalism of the view of man, as 'utilitarian

11 Ibid., Chs. 7 \& 8.

12 For details on ideas of Friedmann, Lipton and Scotts see: Milton Friedmann and L. G. Savage, 'The Utility Analysis of Choices Involving Risk', Journal of Political Economy, Vol. 56, 1948, pp. 279-304; Michael Lipton, 'The Theory of the Optimizing Peasant', Journal of Development Studies, Vol. 4, no. 3, 1968, pp. 327351; James C. Scott, The Moral Economy of Peasant: Rebellion and Subsistence in South East Asia, New Heaven: Yale University Press, 1976, 10-73.

13 Karl Polanyi, The Great Transformation, Boston: Beacon Press, 1944, pp. 43-45. 
atom' ought to 'economize'. ${ }^{14}$ Polanyi suggests the use of a 'substantive economics' in the place of this kind of 'formal economics' that would stress the social relationships in which economic behaviour in pre-market societies was embedded. The 'formal economics' presupposes choice and the ready marketability of land, labor and capital. Relationship of reciprocity shaped economic behaviour in the ancient world but not market relations or profit maximization. ${ }^{15}$ Different approach as the 'instituted process' of economics is required for studying pre-capitalist economies. ${ }^{16}$ According to James Scotts, the principles of reciprocity are never respected in the time of crisis. He has further elaborated the implications of Chayanov's peasant household economy and Polanyi's theoretical perception for interpreting peasant mentality and peasant political behaviour. The notion of risk avoidance and safety first, and by a sustenance ethics involving reciprocity between patron and client of the same moral community guided peasant economic behaviour. Peasants' collective action, by extension, is defensive and restorative against threats to subsistence and intrusions by the capitalist state and the impersonal market forces of capitalism. ${ }^{17}$

In contrast to both the formalist and substantivist views, Marxists laid emphasis on the third dimension of peasantry. In conventional or the orthodox Marxism, the formula made official by Lenin, Stalin and Mao that historical development follows five successive modes of production the primitive, slave, feudal, capitalist and socialist mode of production and peasant economy is feudal characterized by a set of production relations (landowners and peasant producers). In feudal economy, surplus extracted from the peasant producer principally in the form of land rent followed by other imposts.

Asian agriculture has responded population pressure in a number of different ways. Over dependence of population on agriculture has provided flexibility to grow radical features among the peasantry. A number of other characteristic features prevalent in agriculture further accommodated such a situation. In fact, reliance on wage labor gave land-owning community the flexibility to adjust labor supply to their

14 Philip C. Huang, The Peasant Economy and Social Change in North China, Stanford: Stanford University Press, 1985, pp. 4-6.

15 The term reciprocity necessarily indicates to mutual aid and obligation among the kinship groups.

16 Karl Polanyi, Conard M. Arensberg and Henry W. Pearson (eds.), Trade and Empires in Early Empires: Economic in History and Theory, Illinois: The Free Press, 1957, Ch. 12 and 13. 
S. Thapa, Conceptual framework in the ...

optimal needs. Family farms had no such flexibility. It had to tolerate the existence of surplus labor and underemployment. ${ }^{18}$ This kind of situation and the contexts of agriculture had positive outcome in the radical leaning of Asian peasantry.

\section{Productive Forces, Modes of Production and Relationship}

Marx has regarded peasantry as disorganized and incapable of carrying out changes. He believed that this class would disappear with most displaced from the piece of land. However, he was not very much familiar with the peasantry as a group. Productive forces are the unity of means of production and labor. ${ }^{19}$ Marx describes it as the force of production. The forces of production are necessarily linked to the 'relations of production'. Social relations are closely bound up with productive forces. ${ }^{20} \mathrm{He}$ further argues that at a certain stage of development, the productive forces come into conflict with the existing relations of production and those relations turn into fetters. Then there begins an era of social revolution. ${ }^{21}$ The development of exploitation, class division and the institution of private property cannot take place gradually and continuously. A revolution is needed in order to take power out of the hands of one class and rests it in another in order to make it possible for the relations and forces of production to correspond once again.

To study Asian peasantry, the dichotomy of relations and the modes of production are important categories. The modes of production are the unity of the productive forces, which in a certain level, come into conflict with production relations. In the tributary (Asian) mode of production, the state made historical presence out of chiefdoms, agriculture and warfare. The peasantry owes tribute to the rulers transferred in the form of taxes, labor, gifts etc. In this mode of production, state has been the biggest landlord. This form of mode of production controls the production process politically rather than directly. This mode of production is loosely organized. For an instance, the mode of production in Nepal, India, pre-colonial Korea or medieval Japan had such feature. In the class bound societies, the forces of production and the relations of production come into sharp conflict whereas, in the societies

\footnotetext{
18 Huang, Op. Cit., pp. 8-9.

19 http://www.marxists.org/glossary/terms/p/r.htm\#productive forces.

20 Karl Marx, 'The Poverty of Philosophy', Collected Works Vol. 6, Moscow, London and New York: Progress Publisher, Lawrence, Wishart, and International Publisher, 1975-2005, pp.3-104.

21 Ibid., p. 21.
} 
where class division has been disappearing, the contradiction between the forces of production relations can relatively be overcome. As Marx has pointed out, there are no more classes and class antagonisms, thus, the social evolution will cease to be political revolutions. ${ }^{22}$ In fact, present society turns into classless society in which conflicts and revolutions persists to occur. However, in societies where forces of production and production relations remain in conflict, radicalism is likely to take shape. Consequently, peasantry develops radical features to protect or gain their share of rights over the means of production and so on. This kind of feature of peasantry has political nature as well. This situation can be overcome only if peasantry is given appropriate share of rights in the means of production. The latter is necessarily the plot of land, which they cultivate. The political development in Asia immediately before and after the Second World War marked massive involvement and presence of communists. They laid focus to penetrate within the peasant society for political reasons. Their presence in the peasant society and penetration of communist tenets so far were sufficient to radicalize Asian peasantry. Therefore, peasantry did not remain ignorant of the contemporary political economy within their surroundings. It provided impetus to them to raise voice against the landed gentry and all other kinds of usurers. This situation has further politicized the Asian peasant society.

In Marxist classics, ideologues such as Karl Marx, V. I. Lenin, Karl Kautsky, Preobrazhensky and others have analyzed peasants' problems, but without postulating specifically the peasant mode of production. Marx has frequently made use of the phrase 'the peasant mode of production', but he failed to define the term 'mode'. He did not use it in broader sense either.

Marx's characterization of peasants in three different ways can be useful to study peasant societies in Asia.

1. Peasants are a class. They form a class in so far their form of life makes them distinct from other classes. Their form of living and production activities separates them from one another. In fact, their mode of production isolates them from one another instead of bringing them into mutual intercourse. ${ }^{23}$

2. Peasants in the capitalist society hold a contradictory location within class relations in that they are simultaneously, both and

22 Ibid., p. 212; 'Historical Laws and Modes of Production' http://www.etext.org/ politics/AlternativeOrange/4/v4n2_dy4. html

23 Karl Marx, The Eighteen Brumaire of Louis Bonaparte, New York: International Publishers, 1963, p. 124. 
S. Thapa, Conceptual framework in the ...

neither neither bourgeoisie nor proletarian. ${ }^{24}$

3. For Marx, peasantry under capitalism is an outcome of the dissolution of feudalism and as a transitory form. Their downfall originates in the development of large-scale capitalist agriculture. The backward nature of peasant farming dooms peasants to misery and disappearance. ${ }^{25}$

Thus, one who proposes peasant mode of production based on classical Marxism is sneaking out of the context and distorting the fact.

\section{Classical Marxist Perspective on Peasantry}

The views of Marx, Lenin \& Kautsky are classical ideas on peasantry. ${ }^{26}$ Although Marx wrote a little on peasantry, he underestimated their revolutionary potential. His thought on them works as a theoretical model in the study and analysis of peasant society. However, his understanding of peasant society is ambiguous. Various studies about his ideas of peasants point out his derogative attitude towards small-scale agricultural production referring to peasants as the rural idiots. In this context, the classical Marxists are against peasantry because of the original dogmatic belief of Marx himself. ${ }^{27}$ He has written against peasants in his famous treatise 'The Eighteenth Brumaire of Louis Bonaparte' as disorganized without any revolutionary potential. He was filled with undisguised contempt of the peasantry. Marx believed that the law of economic development that functions among different persons gradually transforms peasants, who produce their own means of production into small capitalists who exploit the labor of others. He has identified the process that marked the dissolution of the European peasantry as capital tightening its grip on family producers and feudal dues thus creating even more onerous forms of indebtedness. That is, the peasantry was left to exploit its own labor force in the case of increased capital accumulation for the industrial sector. ${ }^{28}$

24 Karl Marx, Theories of Surplus Value, pt. 1, Moscow: Progress Publisher, 1968, p. 408.

25 Karl Marx, Capital: The Process of Capitalist Production as a Whole, Vol. 3, New York: International Publishers, 1967, pp. 806-808; http://www.marxists.org/archive / marx/works/ 1894-c3/index.htm

26 Marx wrote very little on peasantry. He made partial analysis of peasantry in 'The Eighteenth Brumaire of Louis Bonaparte', in Karl Marx and Fredrick Engel, Selected Works, Vol. 1, pp. 394-487;http://www.marxists.org/archive/marx/works/ sw/progress-publishers/volum 01.htm

27 D. Mitrany, Marx Against Peasants: A Study of Social Dogmatism, London: George Werdenfeld and Nicholson, 1951, p. 41.

28 Ibid., 
The capitalist farmers had to extract surplus value through the employment of free labor that had been created by the expropriation of rural laborers from the land and their subordination to a capitalist. Marx has further elaborated that, in the development of capitalist mode of production, the mass of people expropriated from the land and agriculture is subordinate to capital. His thesis implies the elimination of smallholdings by the incorporation of the capitalist mode of production in the agrarian sector. He also considers the form of production for smallholdings as a transitional phase for the development of agriculture.

With the great commodity production, the growth of capitalist production would inevitably follow involving the differentiation of the peasantry and the employment of wage labor by capitalist owners or tenants. Marx believed that there were ways in which capitalism allows the persistence of peasant agriculture with peasants retaining control over at least some of their main means of production, even though they expected small peasant agriculture would not be able to resist capitalist penetration. He then recognized the gradual and uneven penetration of capitalism within agriculture emphasizing the specificity of agriculture. ${ }^{29}$ Some of Marx's prominent successors such as Lenin and Kautsky also developed such arguments.

The overall impression of Marx's writings is that the growth of commodity production in peasant agriculture and in the wider context of industrial capitalist development, peasant production was determined by the logic of capitalism, however, modified the specific form of production. Although there might be alternative patterns to the classical path of the transition to capitalism in agriculture, in the end, the growth of commodity relations in peasant agriculture would result in the development of agrarian capitalism and the separation of the laborers from the land that is in some forms of class differentiation of peasantry. ${ }^{30}$ Marx held critical view on peasantry and explained them as the 'petit bourgeoisie class' caricaturing them as a sack of potatoes that lack interconnections, common political identity and organization. Marx even despised rural idiocracy as representing at the midst of civilization. ${ }^{31}$ Despite such severe criticism, his outlook on peasantry was ambivalent. On the other hand, Engel had a balanced view of peasantry along with

29 For further details see: T. Cox, Peasants, Class and Capitalism: The Rural Research of L.N. Kristsman and His school, London: Clarendon Press, 1986.

30 Park Gil Sung, Op. Cit., pp. 16-17.

31 Karl Marx and Fredrick Engel, Selected Works, Vol. 1, London: Lawrence and Wishart, 1968, pp. 174-178. 
S. Thapa, Conceptual framework in the ...

clearer understanding of internal stratification and differentiation within the peasant society. He better articulated his position on the role of newly emerging agrarian classes in the attainment of revolutionary objectives. ${ }^{32}$ For him, the farm laborers rather than the tenant farmers or peasant proprietors were the most natural ally of the urban industrial proletariat. ${ }^{33}$ He also viewed peasants as internally split, unorganized and politically impotent unless mobilized by the organized working class. ${ }^{34}$

\section{Mao's Understanding of Peasant Power}

Mao Tse-tung had a good understanding of peasantry in the context of wider scope of Chinese history. He had own views on peasantry and peasant economy. His model of peasantry was more elaborated and comprehensive enough to encompass pre-capitalist quasi-feudal landlord tenant relations as well as capitalist relations. His view of middle class peasants refers to those who own land or only a part of it but rent all their land, all of them have a fair number of implements. According to his understanding of peasant society, the peasant household derive income wholly or mainly from own labor, and as a rule do not exploit others. In many cases, the privileged classes exploit them through payment of rent and extending credits on excessively higher rates of interests. Although middle peasants exploit other lower groups, it did not constitute their source of income. Mao assessed that middle peasants and owner peasants who have typical petty bourgeoisie predilections, are afraid of revolutions whereas poor peasants mainly the tenants are more revolutionary in nature. $^{35}$

Lenin has modified Marxist theory of peasantry. Mao's peasants formed bulk of the revolutionary force and provided a good relationship in the Chinese revolution of 1949. Similarly, popular revolutionary movements of Mexico, Cuba and Vietnam well demonstrated the revolutionary potential of peasantry. ${ }^{36}$ The peasantry of various countries have demonstrated this kind of revolutionary potential and showed up actively in political activities. Their participation in active politics was enough to prove their leadership ability. Peasants have secured such an

Dhanagare, Op. Cit., p. 2.

33 Fredrick Engel, Peasant War in Germany, London: Lawrence and Wishart, 1969, pp. 14-16.

$34 \quad$ Ibid., p. 16.

35 Mao Tse-tung, Selected Works 1, Peking: Foreign Language Press, 1967, pp. 15-20.

36 Jean Chesnaux, Peasant Revolts in China 1840-1849, London: Thames and Hudson, 1973, pp. 121-165. 
influential position in the political economy within their societies that Georgi Plekhanov has described peasantry not as a class but as a notion.

\section{Lenin's Differentiation of Peasantry}

Lenin has critically divided peasant society into three broad categories - poor peasants, middle peasants and rich peasants. His poor peasants were different from the small peasant category of Engel. The pressure of competition, poverty and indebtedness drove them to sell labor not in exceptional cause as implied by Engel, but on a regular basis in order to ensure survival. This has been the characteristic feature of Lenin's poor peasants. ${ }^{37}$ The concept of middle peasant came for the first time in Lenin's writings. He distinguished them from poor peasants and the peasant bourgeoisie. Their position is transitory and their income, being somewhat lower than average expenditure, makes their position in agrarian social structure unstable. They indeed, seem to have much in common with Engel's small peasants. They were, perhaps able to cover average expenditure through income from land, and used some hired labor, but supply more workers than they hire. The process of depeasantization resulting from capitalist development in agriculture sweeps away the middle peasants category and reinforces the extreme ones, namely the peasant bourgeoisie and rural proletariat. Both Marx and Lenin divided rural society into five categories the - landlords, rich peasants, middle peasants, poor peasants and rural proletariats. ${ }^{38}$

Even larger number of rural categories was proposed based on land ownership and agrarian relations. Lenin's rich peasants constitute rural bourgeoisie category, which is distinct from the middle peasant category. The area of land they cultivated exceeded the area that can be worked with family labor alone. Therefore, they hire laborers for cultivation. ${ }^{39}$

The overall impression of Marx's writings is that with the growth of commodity production in peasant agriculture, peasant production is determined by the logic of capitalism. In the end, the growth of commodity relations in peasant agriculture would result in the development of agrarian capitalism and separation of laborers from land that is in the form of class differentiation of the peasantry. Lenin's perceptions of peasantry and agriculture have been very influential on Marxist discourse. Lenin attempted to find empirical support for Marxist theory of transition from feudal to capitalist organization in agriculture.

\footnotetext{
37 Thapa, Peasant Insurgence......, Op. Cit., p. 56

38 Lenin has divided peasant societies in three broad categories. However, his views on division of rural society are based on five general categories.

39

Rahman, Op. Cit., p. XX.
} 
S. Thapa, Conceptual framework in the ...

Lenin's basic contribution to Marx regarding peasantry has been the critical analysis of peasant disintegration. The process of disintegration is the disappearance of old patriarchal peasantry thereby leading to emerge two new classes of rural bourgeoisie and rural proletariat. Lenin's perception and perspective of peasantry has been very much influential on Marxist discourses. His position on differentiation of peasantry and the trajectory of peasant household are very significant in the analysis of peasant society. He supported the Marxist theory of transition from feudal to capitalist organization in agriculture. His analysis of peasant disintegration is the basic contribution to Marxist perspective of peasantry. Lenin believed that:

The phenomenon ... is the process of disintegration of small-scale cultivators and their division into entrepreneur and agrarian laborers. $^{40}$

His views are in sharp opposition to that of Chayanov, who argued that the notion of peasant economy based on independent selfcultivating or self-consumption by the farming family with minimal participation in the market place; and socially organized around the peasant community was no longer existed and could not be recreated. As Lenin believed, the process of disintegration ultimately results in the disappearance of the old patriarchal peasantry and the emergence of two new social classes- the rural bourgeoisie and the rural proletariat. The rural bourgeoisies are independent, commercial farmers or owners of rural commercial or industrial establishments. From this group, a class of capitalist farmers has been created who make cash profits and invest in money lending, trading and purchases. The second category, the rural proletariats includes both poor rural proletariats, who still have some land and those who do not have any land at all, the property less wage laborers.

On peasant differentiation, Lenin believed that the old peasantry is not only differentiating, it is being completely dissolved. It is ceasing to exist and is being ousted by new types of rural inhabitants - types that are the basis of a society in which commodity economy and capitalist production prevail. These types are the rural bourgeoisie (chiefly petty bourgeoisie) and the rural proletariat - a class of commodity producers in agriculture and a class of agricultural wageworkers.

40 Lenin, 'The Development of Capitalism in Russia', Collected Works, Vol. III, Moscow: Progress Publisher, 1964, pp. 21-26; http://www.marxists.org/archive/ Lenin/works/1899/devel/ 
Lenin's attempt to illustrate peasant disintegration is to confirm the operation of the law of capitalist development in the peasant society. He has warned against the rigid transformation and separation of direct producers from land. It is the fundamental accomplishment of capitalism. In the end, the capitalist penetration in agriculture takes place with social slowness and through extraordinarily diverse forms. He considered bondage, usury and labor service, all remnants of pre-capitalist penetration. He also presumes the eventual domination of capitalist relations within agriculture. But the chief weakness of Lenin's perspective is inability to specify the mechanism of the transformation of the peasantry. In a sense, Lenin's arguments are axiomatic one about the emergence and development of capitalism in agriculture based on the logic of capitalism that requires the formation of a home market and therefore, the freeing of the small producer from the means of production.

Peasant community as such is a very much essential and a significant group within the population structure, production process, capital formation and political power structure. ${ }^{41}$ Therefore, their analysis needs to be done within certain approved theoretical paradigm.

\section{Karl Kautsky on Peasantry}

Karl Kautsky's perception of peasantry is very important, ${ }^{42}$ who has reformulated Marxist-Leninist theory of agricultural transformation. He argued that internal differentiation of peasantry would occur and that the peasant is ultimately bound to disappear as a social category under capitalism. However, Kautsky rejects rigid application of the logic of capitalism into agriculture while strongly emphasizing the specificity of agriculture. He also indicates the factors that retard capitalist development in agriculture. He is concerned with explaining the increase in peasant holdings that appeared to challenge the Marxist analysis of capitalist concentration in agriculture. In this context, Kautsky's perception is attractive for suggesting continuing research on the

41 Engel laid importance on peasants' role in political as well as economic structure of the society. Fredrick Engel, 'The Peasant Question in France and Germany', in Selected Works of Karl Marx and Fredrick Engel, Vol. 3, Moscow: Progress Publisher, 1970, p. 457.

42 Karl Kautsky is the successor of Engel in the intellectual leadership of Marxists. He wrote on class, class struggle, historical materialism, and classical Marxism. Karl Kautsky, Selected Political Writings, Hampshire: Macmillan, 1983; Karl Kautsky, Ethnic and Materialistic Conception of History, Eng tr. John B. Askew, Chicago: C. H. Kerr, 1909; Karl Kautsky, Class Struggle, New York: Labour News Co., 1911; Karl Kautsky, The Agrarian Question, Vol. 1, London: Pluto Press, 1988. 
relationship of capitalist development in agriculture and the trajectory of peasant household. The basic factors that inspire peasants to stay on their holdings are under consumption and the overwork by the entire family. The flexible use of family labor and cooperation through the existing rural social network often are more effective and subtle than a parallel large enterprise based on wage labor. Kautsky analyzes the situation in which capitalist mode of production is dominant but the vestiges of other modes remain. Nowhere is there mention of a peasant mode of production or of a peasant based petty commodity mode even though peasants are acknowledged as petty commodity producers. ${ }^{43}$

There exist, however, a fundamental relation between commercial and peasant farmers within the capitalist mode of production. The functional dualism is, however, unstable and the peasant is ultimately bound to disappear as a social category under capitalism. ${ }^{44}$

There are certain differences that exist in the writings of Marx, Lenin and Kautsky regarding the development of capitalism in agriculture. But they agree on the process of capitalist penetration, which led to a greater differentiation of the peasantry into two directly opposite types and that the proletariatization of peasant household is inevitable.

\section{Chayanov's Peasant Household Economy}

A. V. Chayanov, on the other hand elaborated the theory of peasant economy that is distinctly different from Marxist perspective. He argues that the dynamics of rural peasant economy does not constitute a source of social differentiation in the countryside. Perhaps Chayanov's theory is the most serious alternative to the Marxist explanation of agricultural economy. His contribution lies in the identification of peasant economy. Chayanov is the only person who has offered a coherent theory of the phenomenon of the small-scale peasant production as regards to its internal structure and its capacity for survival in a capitalist system. His explanation allows discussing the principal categories that appear in almost all the studies on the subject and are essential for any analysis of peasant economy. ${ }^{45}$ Chayanov's main contribution was firstly, to provide

\footnotetext{
$43 \quad$ Kautsky, The Agrarian Question..., Op. Cit.,

44 Allain de Janvry, The Agrarian Question and Reformism in Latin America, Baltimore: John Hopkins University Press, 1981, pp. 97-99.

45 Several schools have nicely reviewed Chayanov's proposition. See: E. Dormar, 'Review of Chayanov - the Theory of Peasant Economy', American Economic Review, 63: 3, 1968.; B. Kerblay, 'Chayanov and the Theory of Peasantry as a Specific Type of Economy', in Teodor Shanin (ed.), Peasant and Peasant Societies Selected Readings, Harmondsworth: Penguin Books, 1971, pp. 150-160; B. F. Johnson and P. Kilby, Agriculture and Structural Transformation, London: Oxford
} 
a theory of peasant behaviour at the level of the individual family farm and, secondly to show that at the national level peasant economy ought to be treated as an economic system in its own right, and not, as the Marxists claimed, as a formal incipient capitalism, represented by petty commodity production. In Chayanov's view, peasant motivations are different from those of the capitalists; they aim at securing for the needs of the family rather than to make a profit. That is why a central role is given in Chayanov's theory to the notion of balance between subsistence needs and a subjective distaste for manual labor for this determines the intensity of cultivation and the size of the net product. ${ }^{46}$

Chayanov's concern of peasant household economy was the determination of the family labor production in households that are units of production as well as consumption. He also looked at the same statistics. Lenin used to find empirical support for a micro-economic theory of peasant family. Chayanov has listed a set of anomalies that arise from neo-classical and Marxist analysis of peasant economy and proposes a different analytic scheme. His theory begins with the characterization of peasant farm based on farm labor fundamentally different from capitalist enterprises. He viewed that the components of political economy theory such as wage, profit and rent are not seriously treated in the analysis of the peasant labor farm in which the family, because of its year's labor, receives a single labor income and weights its effort against the material results obtained. He argues that a peasant family would produce up to the point where the drudgery of the marginal labor expenditure will equal the subjective evaluation of the marginal utility of the sum obtained by this labor.

Chayanov picked family farm as the central unit of peasant economy, which depends on the labor of the family with no use of wage labor. The family farm is not based along the same lines of capitalist enterprise rather it is oriented to the consumption needs of household and the balance between labor and consumption. Peasant's labor for

University Press, 1975; M. Harrison, 'Chayanov and the Economics of Russian Peasantry', Journal of Peasant Studies, Vol. 12 no. 4, 1975.; D. Hunt, 'Chayanov's Model of Peasant Household Resource Allocation', Journal of Peasant Studies, Vol. 16 no. 3, 1979; Daniel Thorner, 'Chayanov's Concept of Peasant Economy', in D. Thorner, B. Kerblay and R.E.F. Smith (eds.), The Theory of Peasant Economy With a New Introduction by T. Shanin, Wisconsin: The University of Wisconsin Press, 1986; G. Djurfeldt, 'Classical Discussion of Capital and Peasantry: A Critique', in John Harris (ed.), Rural Development: Theories of Peasant Economy and Agrarian Change, London: Hutchinson University Press, 1982. 
Chayanov is aimed at satisfying the household needs of subsistence. In other words, the consumption of the household determines the product of family labor, and sometimes, the degree of self-exploitation. He argues that the ratio of workers to consumers in a household, by determining both household's consumption needs and productive capacity, determines the level of production and extent of the sown area.

The family cycle, the determinant of the balance between labor and consumption, is the core concept of Chayanov's theory of peasant economy. An understanding of peasant household becomes possible through an analysis of its internally generated needs and resources. These needs are specified as present and future family consumption requirements, and the resources are primarily family labor supplies determined solely by the size and composition of the family. He empirically demonstrates how the area under cultivation expanded and contracted as demands and labor power resources changed within the individual peasant household. Overall, this system can be described as a cyclical redistribution of land determined by the life course of farm households. Because of such demographic factors, Chayanov regarded peasantry not as undergoing permanent differentiation but as experiencing cycles of mobility. ${ }^{47}$ The inequalities of farm income and farm size are explained by demographic differentiation. ${ }^{48}$ The main cause of difference in farm size is the demographic changes in the family growth, not the social factors causing peasant households to become capitalist or proletarian, as the classical Marxists have insisted. Chayanov acknowledges that economic factors can be responsible for some degree of differentiation. He does not deny the capital accumulation in rural areas. Nevertheless, he explicitly claims that labor farm will be able to defend its position against large-scale capitalist farms.

47 Teodor Shanin has elaborated main patterns of cyclical mobility of peasant households. For details see: Teodor Shanin, 'Polarization and Cyclical Mobility: The Russian Debate over the Differentiation of the Peasantry', in John Harris (ed.), Rural Development Theories of Peasant Economies and Agrarian Change, London: Hutchinson University Press, 1983.

48 Chayanov's theory has been described as - 'By its social properties more than a given degree of technological development; by social properties stemming from the importance placed upon patriarchal authority by a pre-occupation with the ratio of family land to family labor; by the wish to increase global income rather than the maximization of revenue per family workers; and, of supreme importance , by a family ideal which suffocated individualistic aspirations and emphasized those which worked for the good of the group'. R. M. Smith, 'Some Issues Concerning Families and Their Property in Rural England', in R. M. Smith (ed.), Land, Kinship and Life Cycle, London: Cambridge University Press, 1984, p. 61. 
For Chayanov, different forms of differentiation take place, and given the pressure of a growing commodity economy, class differentiation necessarily exists. His approach is of continuing relevance to contemporary peasant studies and complementary to theories of Marxists.

\section{Proletariatization and Peasantization}

The nature of peasantry and its relationship with capitalism has become popular themes in contemporary times among the experts of peasant societies. The debates are ongoing and are extremely complex. Considerable debates now exit concerning the process of capitalist penetration of rural areas, which advocate the fate of peasantry between peasantization and proletariatization. The Marxists advocate the thesis of the disappearance of peasant agriculture leading to the inevitable proletariatization of the peasantry. ${ }^{49}$ The argument is heavily drawn from Lenin's Development of Capitalism in Russia. It argues that persistence of a non-wage form of production within capitalist economies is essentially a transitional phenomenon and vigorously rejects the notion of a self-regulating, homogenous peasant society and instead, predicts its ultimate disintegration and the increase of proletariatization. ${ }^{50}$ Although consequences of capitalist penetration may vary from one society to another, there is nevertheless similar pattern in the ways in which peasant households are affected. The incorporation of peasant economy into the capitalist system, whatever is endogenous mechanism leads to internal polarization of peasant households. Regarding peasant's wage labor as a critical factor for the transformation of peasant economy, this view attempts to isolate historical forces generating proletariatization rather than to specify internal mechanism of household. In this context, household production shares insignificant percentage of overall agricultural production, marginal at best in producing peasantry and ultimately subordinate to and recognized by the logic of capitalist production.

On the other hand, Chayanovian school or the peasantization theorists advocate (Latin: Campesinista) the thesis of the possibility of survival and strengthening of the family form of production under capitalism. Much of the theoretical support for this group came from the writings of Chayanov, who has focused on the internal dynamics of the

49 The Marxist theorists are the 'Proletarian Theorists'. They became popular as 'Dicampesinista' in the Latin American Academy.

50 Neo-classical economists predicted proletariatization of peasantry accompanying the development of industrial capitalism. 
S. Thapa, Conceptual framework in the ...

peasant household economy. This view claims that peasants' relations with production constitute a specific mode of production that has specific rules of production and consumption as well as some degree of stability. This view is more concerned with the nature and continuity of peasant or simple commodity form of production. It stresses the need for the understanding the persistence of forms of peasant organization such as the family farm with its intensive use of family labor. The approach rests on the model of household mode of economy.

Peasantization as such emphasizes on persistence and stability of peasant forms of production within the capitalist social formation. The argument is that while the development of capitalism has exploited and partially eroded peasant economy, the agrarian sector would not ultimately polarize into capitalists and proletarians. Peasant economy persists because it is substantially able to reproduce the domestic unit, thereby providing a buffer against capitalist encroachment. For this perspective, peasant households have successfully resisted the forces of capitalist transition maintaining a separate type and a particular type of peasant culture that requires analysis on its own terms. ${ }^{51}$ Peasant household is the basic unit of production. The household approach hinges on the economic diversification of the peasant household and thereby, the multiple class relations of a peasant household. Chayanovian approach to study peasant society attempts to account for the existence of multiple class relations, the mode of surplus extraction.

Marxist perspective on peasantry errs by placing great weight on the inevitability of proletariatization without paying attention to the internal dynamics of peasant household, one of the crucial elements for exploring the mechanism of transformation. Chayanov's approach, on the other hand, errs by exclusively focusing on internal dynamics of the peasant household economy.

The theoretical contents and concepts discussed so far provide with sufficient basis to analyze peasant production relations. The classical Marxists believe that peasantry disintegrates and turns into either a proletariat or a bourgeoisie because of the expansion of the capitalist form of production. This notion on peasantry although derived from various analyses and perspectives, is similar to the basic position of the modernization perspective that claims peasants to tie with the traditional

51 K. Vergopoulos, 'Capitalism and Peasant Productivity, Journal of Peasant Studies, Vol. 5 no. 4, 1978; Harrison, Loc. Cit., 
system, and is an obstacle to development. The peasantry is, then to disappear with the advancement of modernization.

The accumulation of capital separates the direct producers from the means of production and makes the conditions of survival more insecure and contingent, thereby permitting the realization of proletariatization of peasant households. Although there has been considerable progress in capitalist penetration with the modernization of agriculture, there is also ample evidence of peasantization. K. Heying has correctly observed in the Latin American context that:

There is evidence that there has also been a process of depeasantization and proletariatization in Latin America. But at the same time, we see the persistence and reproduction of peasant units of production, which continues to be the main source of subsistence for a large part of the rural population. To adopt a rigid position in a polarized debate between the peasantization and proletariatization, various schools of thought would imply either oversimplification of reality or else a false dilemma. The question of whether one approach is analytically adequate also depends on the question of how far it is empirically applicable. $^{52}$

Because capitalism needs, a free and landless worker who must sell his labor does not provide the additional alternative of capitalist development proceeding without an increase in depeasantization. The advance of capitalist relations of production does not necessarily imply a reduction in the number of smallholdings or proletariatization of the peasant household.

The process of proletariatization is not as rigid as the Marxists suggest. It is relatively slow in most underdeveloped countries compared to industrialized nations. In the context of developed world, there is a pre-dominant trend of generalized proletariatization as to speak of the extinction of the peasant class. The peasant household deprived of the means of production and depending for its subsistence and reproduction on wages alone does not constitute a generalized category for the rural peasants. Therefore, proletariatization is partial and slow even though the amount of total surplus value that can be extracted has increased. Now peasants are forced to multiple economic activities that is household rely on broad range of economic activities including agricultural production,

52 K. Heying, 'The Principal Schools of Thought in Peasant Economy'. CEPAL Review, Vol. 16, 1982, Quoted in Park Gil Sung, Op. Cit., pp. 27-28. 
S. Thapa, Conceptual framework in the ...

craft production, agricultural wage labor, non-agricultural wage labor, migratory wage labor and so on. The Orthodox Marxist approach particularly that of Lenin takes the direct producers to unusual access on the means of production. This has been regarded as the entry point of the class typology to explain social differentiation. Lenin has characterized the stratification of peasant household by the degree of land as a commodity and thus, as a wage labor relation. Rich peasants also consider land as commodity and bulk of its production consist of commodities for the market. The poor have to rent land from the rich and sell labor. An unequal access of peasant household to the means of production does not provide an explanation of how a peasant household can maintain its subsistence and overtime reproduce the household as a unit of production and consumption as is the historical fact.

The functionalist reproduction theorists argue that peasantry is 'functional to capital as a source of cheap food and a pool of semi proletarian labor'. Peasant economy continues to exist because the capitalist sector needs to extract labor and resources from it constantly to reproduce itself. Capitalism selectively sustains certain forms of smallscale peasant or simple commodity production, with cheaper reproduction labor costs for the capital sector. ${ }^{53}$

Marxist perspective especially the proletarian thesis faces critique in reference to agrarian reality that shows existence of the peasant forms of production under capitalism. Similarly, the Chayanovian framework also faces critique focusing on the theory of the peasant economy itself. Peasant household is the basic unit of production and reproduction. Chayanov's theory hinges on the observation of economic diversification of peasant household and multiple class relations. These perspectives are crucial in analyzing peasants' radical political activities in one way or another. Peasant economy has close relationship with political motivation of peasant society. The slogans raised so far by political activists in favor of peasantry pertaining to land ownership, rent reduction and so on have direct impact on entire peasant society in many Asian countries. This, in turn, has far-reaching consequences on existing political set up. Thus in Asia, peasantry constitute as a force that has positive impact on social revolution. Peasantry attempts to maintain its sustenance and social reproduction taking advantage of internal resources under the pressure from exogenous structural changes. The survival strategy focuses on relationship between changing forms of

$53 \quad$ Park Gil Sung, Op. Cit., pp. 30-31. 
production and domestic group formation through which the immediate material needs are met. ${ }^{54}$ The perspective confers a theoretical significance to the household as something more than just a response to outside historical forces. The multiple levels of analysis are united in a single conceptual framework. The theoretical considerations are the ways how peasant society can be understood and analyzed. Historians, anthropologists and political scientists use it as the conceptual tool to go deep into the peasant society particularly in East Asian, South Asian and South East Asian historical contexts. Regarding peasants' potential for introducing political changes, Marxism and Maoism remained very much forceful in Asian peasant societies. Due to political potential of peasantry, Mao has laid higher emphasis on peasant power in Chinese revolution. Various scholars have analyzed peasant society using conceptual paradigms. Since the contexts of Asian peasantry differ greatly to the peasantry in Europe, land tenure conditions as well as other situations greatly vary between them. Therefore, in some cases there are contextual differences. It is important to note that Asian peasants grew more political with the growing communist movement in Asia. Some studies have carelessly ignored political or revolutionary potential of Asian peasantry. The infiltration of Communist party among the peasantry in different Asian countries gave an impetus to mobilize peasants and develop radical features. Radical and revolutionary activities of Asian peasants are of greater significance to study Asian history and society. Considering the significance of peasants' power, peasant radicalism has been an important theme to study using certain approved conceptual frames.

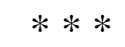

54 C. Goldin, 'Family Strategies and Family Economy in the Late $19^{\text {th }}$ Century - the Role of Secondary Workers', in T. Hershberg (ed.), Philadelphia - Work, Space, Family and Group Experience in the Nineteenth Century, Oxford: Oxford University Press, 1981, Quoted in Park Gil Sung, Op. Cit., p. 34. 